\title{
BIOMONITORING PENCEMARAN UDARA MENGGUNAKAN BIOINDIKATOR LICHENES DI KOTA MADIUN
}

\author{
Anikhotul Ihrom ${ }^{1)}$, Ani Sulistyarsi ${ }^{2)}$ \\ ${ }^{1,2)}$ Pendidikan Biologi, FPMIPA IKIP PGRI Madiun \\ Email: anismasa81@yahoo.com
}

Diterima 8 Agustus 2015 disetujui 23 Oktober 2015

\begin{abstract}
Bioindicators can be used to determine levels of air pollution of an area by analyzing the content of pollutants lead in bioindicators. Lichenes growing on the bark as bioindicators for measuring the concentration of lead in air pollutants resulting from motor vehicle emissions. The aim of research to determine differences in the levels of lead $(\mathrm{Pb})$ using bioindicators Lichenes Madiun. Samples were taken by random sampling technique. $\mathrm{Pb}$ content measurement using Atomic Absorption Spectrophotometer (AAS). The results showed Pb levels in different areas of the City of Madiun there are significant differences. Traffic levels affect the levels of Pb .
\end{abstract}

Keywords: Lichenes, lead, bioindikator

\section{PENDAHULUAN}

Meningkatnya alat-alat transportasi di kota jalur darat khususnya jalan raya menimbulkan asap kendaraan yang dapat menimbulkan akumulasi yang berdampak negatif bagi makhluk hidup. Kemajuan teknologi transportasi bertujuan untuk meningkatkan kesejahteraan manusia, akan tetapi seiring dengan kemajuan alat-alat transportasi tersebut dapat menyebabkan polusi atau pencemaran udara. Asap kendaraan bermotor merupakan sumber pencemaran udara karena banyak mengandung zat-zat berbahaya misalnya $\mathrm{NO}_{2}, \mathrm{HC}, \mathrm{Cl}_{2}, \mathrm{O}_{3}, \mathrm{CO}$, partikel debu TSP dan timbal $(\mathrm{Pb})$.

Pencemaran udara merupakan masuknya makhluk hidup, zat, energi, atau komponen lain ke udara oleh kegiatan manusia atau proses alam sehingga terjadi penurunan kualitas udara sampai tingkat tertentu yang menyebabkan udara menjadi kurang atau tidak berfungsi sesuai dengan peruntukannya (Ratna, 2012). Salah satu bahan pencemar udara yang sangat berbahaya yaitu $\mathrm{Pb}$. Timbal $(\mathrm{Pb})$ berasal dari bensin yang digunakan sebagai bahan bakar kendaraan bermotor. Bensin yang digunakan sebagai bahan bakar kendaraan bermotor adalah bensin dengan bilangan oktan tinggi, yaitu bensin yang diberi senyawa timbal tertra etil dan timbal tetra metil. Bilangan oktan tinggi pada bensin efeknya sangat buruk untuk kualitas udara.

Timbal $(\mathrm{Pb})$ sangat berbahaya bagi manusia dapat merusak jaringan saraf, fungsi ginjal, menurunnya kemampuan belajar, dan membuat anak-anak bersifat hiperaktif. Adanya dampak negatif timbal terhadap manusia maka diperlukan tindakan untuk mereduksi timbal dari udara. Salah satu metode untuk biomonitoring pencemaran timbal di udara adalah dengan menggunakan berbagai macam metode, tetapi perlu mempertimbangkan kondisi alam sehingga tidak menimbulkan efek samping. Salah satu cara penanggulangan pencemaran timbal secara biologis yaitu menggunakan bioindikator tumbuhan lumut Lichenes.

Lichenes dapat digunakan sebagai bioindikator adanya pencemaran udara karena mudah menyerap zat-zat kimia yang ada di udara dan dari air hujan (Usuli et al., 2014). Penelitian tentang biomonitoring pencemaran udara dengan bioindikator Lichenes sebelunya belum ada di kota Madiun. Penelitian tentang biomonitoring pencemar timbal menggunakan lumut Lichenes perlu dilakukan sebagai bioindikator pemantau kualitas udara di kota Madiun. 


\section{METODE}

Pengambilan sampel dilaksanakan di tiga kawasan tingkat kepadatan kendaraan yang berbeda Kota Madiun yaitu kawasan padat lalu lintas, kawasan sedang lalu lintas dan kawasan sepi lalu lintas. Uji kadar timbal $(\mathrm{Pb})$ dilaksanakan di Balai Riset dan Standarisasi Industri Surabaya. Alat dan bahan yang digunakan yaitu: cutter, pemanas listrik, labu ukur, gelas piala, gelas ukur, pipet volume, kaca alroji, filterberpori, gunting, corong gelas, dan Spektrophotometer Serapan Atom (SSA). Lichenes diambil dari pohon dengan jarak pengambilan 0,5 m, $1 \mathrm{~m}$, dan 1,5 $\mathrm{m}\left(\mathrm{HNO}_{3}\right)$, $\mathrm{Mg}\left(\mathrm{NO}_{3}\right)_{2}, \mathrm{H}_{2} \mathrm{O}$, etanol, $\mathrm{HCl}, \mathrm{HNO}_{3}$, air suling, hidrogen peroksida $\mathrm{H}_{2} \mathrm{O}_{2}$, dan larutan induk timbal.

Prosedur kerja sebagai berikut: menimbang $20 \mathrm{~g}$ Lichenes dan dimasukkan ke dalam cawan porselen atau piala gelas Pyrex $100 \mathrm{ml}$, menambahkan dengan menggunakan pipet $10 \mathrm{ml}$ larutan magnesium nitrat dalam etanol, diaduk menggunakan batang pengaduk dan dibilasi dengan etanol 95\%. Menguapkan etanol diatas penangas air sambil diaduk sekalisekali, kemudian dipanaskan diatas penangas listrik (menutup piala gelas dengan kaca alroji). Memindahkan piala gelas ke dalam tanur dengan suhu $200^{\circ} \mathrm{C}$ dan secara bertahap menaikkan suhu sampai $500^{\circ} \mathrm{C}$ selama 2 jam dan diabukan sepanjang malam pada suhu $450-500^{\circ} \mathrm{C}$. Mengangkat piala gelas dari tanur dan dibiarkan dingin di atas asbes. Apabila masih terdapat sisa karbon, setelah dingin ditambahkan $1 \mathrm{ml}$ air dan $2 \mathrm{ml} \mathrm{HNO}_{3}$, kemudian dikeringkan diatas penangas air. Dipanaskan kembali pada suhu $500^{\circ} \mathrm{C}$ selama 1 jam. Semua prosedur diulang sampai diperoleh abu yang berwarna putih. Menambahkan $5 \mathrm{ml}$ larutan campuran $\mathrm{HCl}$ dan $\mathrm{HNO}_{3}$ ke dalam abu melalui dinding piala gelas dan dipanaskan diatas penangas air sampai abu larut. Memindahkan larutan secara kuantitatif ke dalam labu ukur $100 \mathrm{ml}$, kemudian mengimpitkan labu dengan air suling. Menyaring dengan larutan saring, mengerjakan blanko dengan menggunakan pereaksi yang sama. Membaca absorbsi larutan standar, blanko dan Lichenes dengan menggunakan SSA pada panjang gelombang 283,3 nm untuk timbal. Membuat kurva kalibrasi dengan sumbu $\mathrm{Y}$ sebagai absorbansi dan sumbu X sebagai konsentrasi (dalam ppm) serta menghitung kandungan logam dalam Lichenes. menggunakan rumus sebagai berikut.

Kandungan
$\operatorname{logam}(u \mathrm{~g} / \mathrm{g})=\frac{u \mathrm{~g} \text { logam } / \mathrm{ml} \text { darikurva kalibrasi x v }}{\mathrm{M}}$

\section{HASIL DAN PEMBAHASAN}

Berdasarkan hasil uji hipotesis diketahui bahwa kepadatan lalu lintas (padat, sedang, sepi) berpengaruh nyata terhadap kadar timbal Lichenes. Tinggi jarak pengambilan $(0,5 \mathrm{~m}, 1 \mathrm{~m}, 1,5 \mathrm{~m})$ tidak berpengaruh terhadap kadar timbal Lichenes. Kawasan padat lalu lintas dan tinggi jarak pengambilan Lichenes $0,5 \mathrm{~m}, 1$ $\mathrm{m}$, dan 1,5 m memiliki kadar timbal 0,78 $\mathrm{mg} / \mathrm{kg}, \quad 1,21 \mathrm{mg} / \mathrm{kg}$, dan $1,61 \mathrm{mg} / \mathrm{kg}$. Kawasan padat lalu lintas merupakan kawasan dengan kadar timbal tertinggi, karena jarak pohon relatif dekat dengan jalan raya dan banyaknya kendaraan yang melewati kawasan sehingga emisi gas buang kendaraan bermotor langsung menempel pada pohon di pinggir jalan. Suhadiyah et al., (2014) dalam penelitiannya menyatakan bahwa semakin dekat tanaman dengan sumber emisi maka $\mathrm{Pb}$ udara yang terabsorbsi semakin banyak.

Kendaraan sepeda motor dan mobil menggunakan bahan bakar jenis bensin sedangkan kendaraan truk menggunakan bahan bakar jenis solar. Bensin dan solar merupakan bahan bakar yang mempunyai nilai bilangan oktan tinggi sehingga di dalamnya banyak terkandung logam berat khususnya timbal $(\mathrm{Pb})$. Truk merupakan penyumbang emisi terbesar, karena solar sebagai bahan bakar truk mengandung timbal lebih tinggi dari pada bahan bakar bensin. Banyaknya truk menyebabkan udara 
sekitar menjadi tercemar dan banyak debu. Pencemaran udara di kawasan jalan dibuktikan dengan adanya kandungan timbal yang tinggi pada Lichenes. LichenesLichenes yang terdapat di kawasan jalan raya sangat terbatas, hanya Lichenes tertentu yang dapat hidup di kawasan jalan raya padat kendaraan.

Kawasan sedang lalu lintas dan tinggi jarak pengambilan $0,5 \mathrm{~m}, 1 \mathrm{~m}$ dan 1,5 $\mathrm{m}$ memiliki kadar timbal <0,01 mg/kg, 0,45 $\mathrm{mg} / \mathrm{kg}$ dan $0,65 \mathrm{mg} / \mathrm{kg}$. Kawasan sepi lalu lintas dengan tinggi jarak pengambilan 0,5 $\mathrm{m}, 1 \mathrm{~m}$, dan $1,5 \mathrm{~m}$ dari permukaan tanah memiliki kadar timbal paling rendah yaitu < $0,01 \mathrm{mg} / \mathrm{kg}$, karena lalu lintas kendaraanpun belum terlalu banyak, sekitar 18 kendaraan perjam. Meskipun sepeda motor dan mobil menggunakan bahan bakar bensin tetapi kendaraan yang melewati sangat sedikit sehingga termasuk kawasan sepi lalu lintas, oleh karena itu kadar timbal Lichenes cenderung rendah. Lichenes yang menempel pada kawasan sepi lalu lintas mengandung sedikit logam berat timbal $(\mathrm{Pb})$. Data kadar timbal selanjutnya diolah menjadi grafik pada Gambar 1.



Gambar 1. Kadar Timbal dengan Daerah Kawasan yang Berbeda

Hasil penelitian ini menunjukkan bahwa kepadatan lalu lintas dan jarak tanaman dengan jalan raya berpengaruh terhadap kadar timbal. Banyak kendaraan bermotor yang melewati suatu kawasan dan jarak tanaman dengan jalan raya maka kadar timbal yang terkandung dalam Lichenes akan menjadi tinggi. Hasil penelitian ini sejalan dengan penelitian yang dilakukan oleh Sri Amintarti (2011) bahwa banyaknya jumlah kendaraan yang lewat menunjukan banyaknya jumlah polutan di udara, hal ini disebabkan karena adanya emisi gas yang berasal dari kendaraan bermotor.

Hasil pengukuran kadar timbal di tiga kawasan penelitian bahwa Lichenes dapat menyerap timbal dari udara. Terdeteksinya timbal pada Lichenes berkaitan dengan jumlah timbal di udara dan struktur morfologi Lichenes yang kasar dan bersisik sehingga timbal mudah untuk melekat. Kawasan dengan kendaraan bermotor yang padat memiliki kecepatan angin, suhu, cahaya, kecepatan kendaraan lebih tinggi dibandingkan kawasan sedang dan sepi kendaraan, sedangkan kelembaban udara lebih rendah di jalan padat kendaraan bermotor. Kadar timbal pada kawasan padat lalu lintas lebih tinggi dibandingkan kadar timbal di dua kawasan lainnya. Emisi merupakan hasil samping dari pembakaran yang terjadi dalam mesin-mesin kendaraan. Timbal yang merupakan hasil samping dari pembakaran ini berasal dari senyawa tetrametil- $\mathrm{Pb}$ dan tetraetil- $\mathrm{Pb}$ yang selalu ditambahkan dalam bahan bakar kendaraan bermotor dan berfungsi sebagai anti ketuk (anti knock) pada mesin-mesin kendaraan.

\section{SIMPULAN}

Berdasarkan pembahasan dapat disimpulkan bahwa adanya perbedaan kadar Timbal $(\mathrm{Pb})$ pada bioindikator Lichenes di beberapa jalan utama di kawasan kota Madiun. Pengaplikasian dapat dilakukan pada tanaman bioindikator lainnya mengatasi masalah pencemaran udara.

\section{DAFTAR PUSTAKA}

Badan Standarisasi Nasional (BSN). (2005). Cara Uji Kadar Timbal $(\mathrm{Pb})$ dengan Metoda Destruksi Basah 
Menggunakan Spectrofotometer Serapan Atom. SNI 19-7119.42005. (http://sisni.bsn.go.id/). Diakses tanggal 9 Maret 2015.

Ratna Rima Melati. (2012). Kamus Biologi. Surakarta : PT Aksara Sinergi Media.

Sri Amintarti. (2011). Akumulasi Timbal (Pb) Dan Struktur Daun Angsana (Pterocarpus Indicus Willd ) Sebagai Tumbuhan Peneduh Jalan Di Kota Banjarmasin. Banjarmasin.

(http://id.portalgaruda.org/).

Diakses tanggal 23 Maret 2015.

Sri Suhadiyah, Roland A Barkey, dan Elis

Tambaru. (2014). Kolerasi Kondisi
Daun Terhadap Kadar Pb, dan Klorofil Daun Hibiscus tiliaceus dan Swletenia macrophylla King Dikampus Universitas Hasanuddin Makassar. Makassar. Universitas Hasanuddin Makassar. (http://publikasilppm.unhas.ac.id/index.php). Diakses tanggal 25 Februari 2015.

Usuli, Yuliani., Uno.D, Wirnangsi dan Baderan, Dewi W. K (2014). Lumut Kerak Sebagai Bioindikator Pencemaran Udara. Universitas Negeri Gorontalo, Gorontalo. (http://eprints.ung.ac.id/5108/). Diakses tanggal 2 Maret 2015. 